\title{
The occurrence of the parasitic amphipod Trischizostoma crosnieri Lowry \& Stoddart, 1993 (Amphipoda: Amphilochidea: Lysianassida) in a methane seep site in the southeastern Pacific
}

\author{
Jorge Pérez-Schultheiss ${ }^{1}(\mathbb{D})$ \& Javier Sellanes ${ }^{2}$ \\ ${ }^{1}$ Área Zoología de Invertebrados, Museo Nacional de Historia Natural, Santiago, Chile \\ ${ }^{2}$ Departamento de Biología Marina \& Núcleo Milenio "Ecología y manejo sustentable de islas oceánicas" \\ Facultad de Ciencias del Mar, Universidad Católica del Norte, Coquimbo, Chile \\ Corresponding author: Jorge Pérez-Schultheiss (jorge.perez@mnhn.gob.cl)
}

\begin{abstract}
The genus Trischizostoma Boeck, 1861 is a cosmopolitan group of parasitic and symbiotic aristoidean amphipods whose distribution is poorly known, with scarce specimens reported principally from pelagic environments until $3655 \mathrm{~m}$ depth. In this note, Trischizostoma crosnieri Lowry \& Stoddart, 1993, a species described for the southwest Pacific, is recorded for the first time in the southeast Pacific. The species was known previously only from a female specimen, described from the Philippines, with two additional unpublished records from the east coast of Australia and Tasmania. The specimens studied herein were obtained at $874 \mathrm{~m}$ depth, $36 \mathrm{~nm}$ to the northwest of Concepción, Biobío Region, in a methane seep site. However, the relationship between this species with this particular habitat is still uncertain. The genus Trischizostoma has been cited for the Nazca and Salas y Gómez ridges; nevertheless, our finding constitutes the first record of a species at the continental margin off Chile, raising to four the known species of the genus for Chilean waters.
\end{abstract}

Keywords: Trischizostoma; parasitic amphipod; methane seep; Chile

The genus Trischizostoma Boeck, 1871 includes 18 species, most of them inhabiting pelagic and bathypelagic environments in all oceans, excepting the Antarctic, with a higher diversity in the southern hemisphere, north to $40^{\circ} \mathrm{S}$, where $80 \%$ of the species have been recorded (Winfield et al. 2016). These amphipods are symbionts of benthic organisms or ectoparasites of fishes, and present important adaptations for this lifestyle, as an inverted propodus of gnathopod 1 in adults as well as styliform mouthparts (Freire \& Serejo 2004).

In Chile, three species of Trischizostoma have been reported, described from the Nazca and Salas y Gómez submarine ridges, between 50 and $540 \mathrm{~m}$ depth (Vinogradov 1990, Pérez-Schultheiss 2016). However, there is no information about these amphipods in deepsea marine areas associated with the continental margin. In this note, we report an additional species of Trischizostoma in Chile, discovered at the continental margin off Concepción, Biobío Region. Details are provided to recognize this species, and its presence in the southeast Pacific is discussed.

The studied specimens are deposited in the Biological Collections of the Universidad Católica del Norte, Coquimbo (SCBUCN), and the amphipod collection of the Museo Nacional de Historia Natural, Chile (MNHNCL AMP). The specimens were collected during a cruise onboard RV Vidal Gormaz, Chilean Navy, to study the Concepción methane seep area (CMSA) (Sellanes et al. 2008). Samples at this site were obtained with a modified Agassiz trawl, $1.5 \mathrm{~m}$ horizontal aperture, and $10 \mathrm{~mm}$ mesh size at the codend, operated in a $10 \mathrm{~min}$ haul. One specimen was thoroughly dissected for microscopic observation. The dissection was carried out in $70 \%$ alcohol, under a dissecting microscope, and the appendages were mounted as semi-permanent slides in glycerol, sealed with transparent nail varnish. The mounted appendages

Corresponding editor: Ingo Wehrtmann 
were studied under a microscope, photographs were captured with an attached digital camera, and plates were prepared with the program Adobe Photoshop.

Order Amphipoda Latreille, 1816

Suborder Amphilochidea Boeck, 1871

Infraorder Lysianassida Dana, 1849

Parvorder Lysianassidira Dana, 1849

Superfamily Aristioidea Lowry \& Stoddart, 1997

Family Trischizostomatidae Lilljeborg, 1865

Genus Trischizostoma Boeck, 1871

\section{Trischizostoma crosnieri Lowry \& Stoddart, 1993}

Trischizostoma crosnieri Lowry \& Stoddart, 1993: 103-107, figs. 31-33; Vinogradov 2004: 46 (key); Winfield et al. 2016: 8 (map).

Material examined: one adult $q$ (SCBUCN N 4213 ), $16.5 \mathrm{~mm}$, with juveniles in the marsupium and one adult $ᄋ$ (MNHNCL AMP-15333), $22.8 \mathrm{~mm}$, with setose oostegites, but without juveniles in marsupium (Fig. 1); both specimens with the following collection data: off Trehuaco, Mela, Nuble, Concepción, Biobío Region, 36²1'27.65"S, 7343'39.19"W, 874 m depth, October 2, 2007, RV Vidal Gormaz. Muddy bottom with authigenic carbonates derived from the process of anaerobic oxidation of methane. Coll. J. Sellanes.

\section{Diagnosis}

Maxilliped (MXP, Fig. 2): palp 4-articulate, much longer than the outer plate. Gnathopod 1 (GN1, Fig. 2): posterior margin of dactylus smooth, palm-covered with similar and uniformly distributed robust setae, propodus 1.5 times as wide as long. Pereopod 4 (P4, Fig. 2): coxa deep, merus markedly wide. Pereopod 5 (P5, Fig. 2): posterior lobe of basis produced posterodistally. Pereopod 7 (P7, Fig. 2): dactylus normal, slender. Uropod 3 (U3, Fig. 2): peduncle distinctly shorter than rami. Telson (T, Fig. 2): partly cleft.

Trischizostoma crosnieri is known only from a female of $29 \mathrm{~mm}$, collected close to the Philippines $\left(13^{\circ} 44^{\prime} \mathrm{N}, 120^{\circ} 32^{\prime} \mathrm{E}\right)$, between 682 and $770 \mathrm{~m}$ depth (Lowry \& Stoddart 1993). Additional specimens, identified by H.E. Stoddart and preserved in the Australian Museum, correspond to a female from southeast Australia (AM P.69093, 33 $355^{\prime} \mathrm{S}, 152^{\circ} 00^{\prime} \mathrm{E}$ ) and a male from east Tasmania (AM P.69094, $41^{\circ} 25^{\prime} \mathrm{S}$, $148^{\circ} 43^{\prime} \mathrm{E}$ ) (ALA 2017). The two female specimens studied here were obtained at $874 \mathrm{~m}$ depth, $36 \mathrm{~nm}$ northwest of Concepción, Biobío Region, and represent the first record of the species outside the southwest Pacific (Fig. 3).

The material's morphological characteristics are in full agreement with the original description of Trischi-

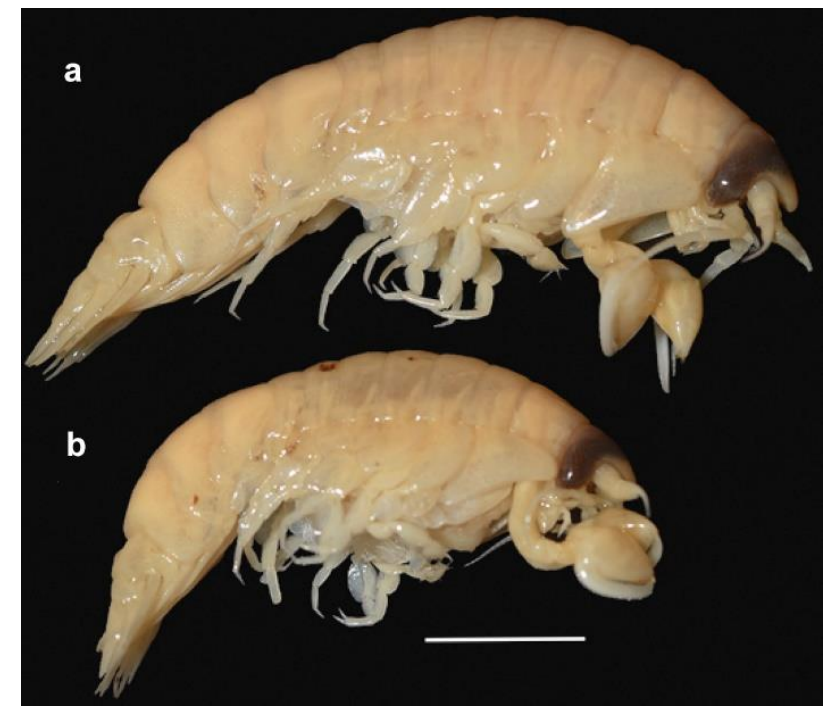

Figure 1. Habitus of Trischizostoma crosnieri Lowry \& Stoddart, 1993. a) Female specimen (MNHNCL AMP15333), b) female specimen (SCBUCN No4213). Scale: 5 $\mathrm{mm}$.

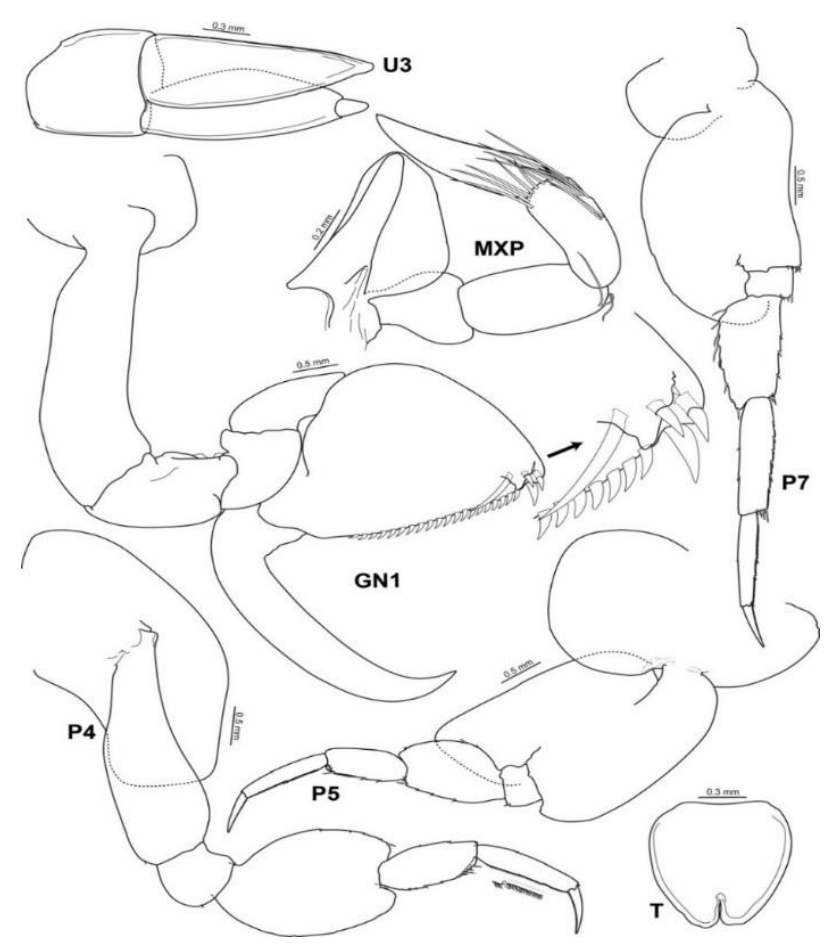

Figure 2. Trischizostoma crosnieri Lowry \& Stoddart, 1993. Female MNHNCL AMP-15333. GN1: gnathopod 1, MXP: maxilliped, P4, P5, and P7: pereopods 4-5, 7, U3: uropod 3, T: telson.

zostoma crosnieri Lowry \& Stoddart, 1993. Barnard (1961) recognized the occurrence of two groups within the genus Trischizostoma, suggesting that they might merit recognition at the genus level. The first group 


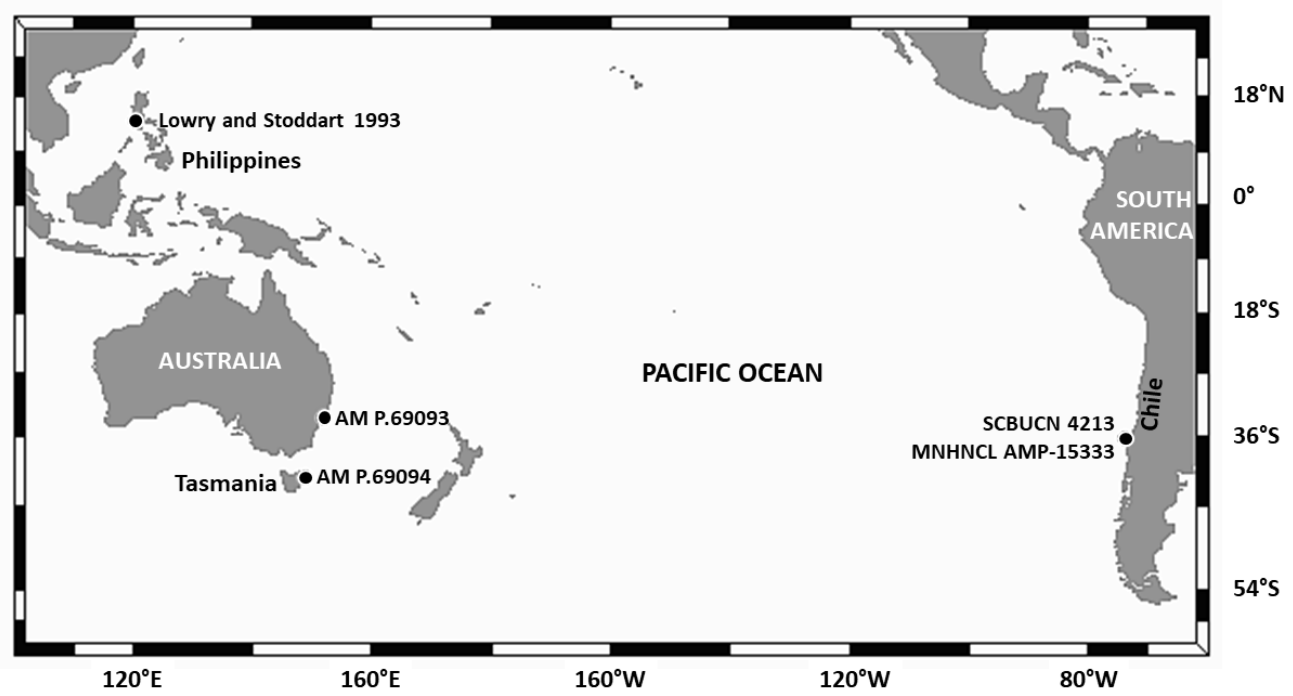

Figure 3. Known geographic records of specimens of the amphipod Trischizostoma crosnieri Lowry \& Stoddart, 1993.

includes only three species: T. paucispinosum K.H. Barnard, 1916, T. remipes Stebbing, 1908, and T. serratum K.H. Barnard, 1925, all of them described from the southeast Atlantic and the southwest Indian oceans, in symbiotic association with benthic organisms (Freire \& Serejo 2004, Vinogradov 2004). These species are characterized by a small rostrum, mouthparts slightly modified, and a telson half cleft.

The second group includes the remaining 15 species, characterized by a sizeable conspicuous rostrum, strongly styliform mouthparts, and an entire telson. These species present pelagic habits and are ectoparasites of fishes. Although T. crosnieri shows a slightly cleft telson, other characters suggest that it belongs to this species group, within which it would be closely related to T. raschi Esmark \& Boeck, in Boeck 1861 (cf. Lowry \& Stoddart 1993).

On a global scale, records of the genus Trischizostoma are scarce, with most species reported only from their respective type localities. Only two species have been registered in more than one geographical area. Trischizostoma richeri Lowry \& Stoddart, 1994 is the only amphioceanic species collected in the Pacific (New Caledonia) and Atlantic oceans (Brazil). T. raschi has been reported from two widely separated localities in the Atlantic (Brazil and Norway) (Winfield et al. 2016). With the material studied herein, T. crosnieri is confirmed as the third widely distributed species with records in the southwest and now in the southeast Pacific.

Although some lysianassidiran species show a wide distribution in the deep ocean, evidence indicates that many correspond to complexes of several closely related species with more restricted distribution (Havermans 2016). The material studied here closely agrees morphologically with the original description of T. crosnieri; however, the conspecificity should be confirmed with molecular analyzes once further suitable material is available.

Finally, it is interesting to note that the reported specimens were collected during a cruise oriented to the study of methane seeps off central Chile. At the station where the specimens were retrieved, live seep animals were also present (e.g. Calyptogena gallardoi, Lamellibrachia sp. and Thyasira methanophila), along with a diverse opportunistic fauna (Sellanes et al. 2008). Some animals are obligated to live in seep sites in those chemosynthetic environments (e.g. those that have endosymbiont chemosynthetic bacteria); others are just opportunistic, benefiting from food and refuge generated at those sites (Sellanes et al. 2010). There is no evidence supporting any dependence of $T$. crosnieri with methane seeps. Although lysianassoid amphipods have been previously mentioned from other seep sites worldwide (e.g. Bellan-Santini 1997, Kilgallen 2009, Rybakova et al. 2013), the species is probably associated as a parasite with some undetermined local fish species.

\section{ACKNOWLEDGMENTS}

To Jorge Avilés (Sala de Colecciones Biológicas de la Universidad Católica de Norte, Coquimbo) for the selection and loan of the material examined in this study. This work was partly funded by FONDECYT 1181153 project. 


\section{REFERENCES}

Atlas of Living Australia (ALA). 2017. Trischizostoma crosnieri Lowry \& Stoddart, 1993. [http://bie.ala.org. au/species/urn:Isid:biodiversity.org.au:afd.taxon:7f52 6d77-087c-45f8-a3a5-0b79f3e818da]. Reviewed: May 10, 2018.

Barnard, J.L. 1961. Gammaridean Amphipoda from depths of 400-6000 meters. Galathea Report, 5: 23128.

Bellan-Santini, D. 1997. Amphipods of the cold seep community on the South Barbados Accretionary Prism. Crustaceana, 70: 1-30.

Boeck, A. 1861. Bemaerkniger angaaende de ved de norske Kyster forekommende Amphipoder. Forhandlinger ved de Skandinaviske naturforskeres ottende mode i Kobenhavn, 8: 631-677.

Boeck, A. 1871. Crustacea Amphipoda borealia et arctica. Forhandlinger i Videnskabs-Selskabet i Christiana, 1870: 83-280.

Dana, J.D. 1849. Synopsis of the genera of Gammaracea. American Journal of Sciences and Arts, 8: 135-140.

Freire, P. \& Serejo, C. 2004. The genus Trischizostoma (Crustacea: Amphipoda: Trischizostomidae) from the southwest Atlantic, collected by the REVIZEE Program. Zootaxa, 645: 1-15.

Havermans, C. 2016. Have we so far only seen the tip of the iceberg? Exploring species diversity and distribution of the giant amphipod Eurythenes. Biodiversity, 17: 12-25.

Kilgallen, N.M. 2009. New species of lysianassoid Amphipoda (Crustacea) associated with seamounts, marine canyons and cold seeps of New Zealand. Zootaxa, 2298: 1-30.

Latreille, P.A. 1816. Nouveau dictionnaire d'histoire naturelle, appliquée aux arts, à l'agriculture, à l'économie rurale et domestique, à la médicine, etc. Déterville, Paris.

Lilljeborg, W. 1865. On the Lysianassa magellanica $\mathrm{H}$. Milne Edwards and on the Crustacea of the suborder Amphipoda and subfamily Lysianassina found on the coast of Sweden and Norway. The Royal Academy Press, Uppsala, 37 pp.

Received: 6 April 2020; Accepted: 29 December 2020
Lowry, J.K. \& Stoddart, H.E. 1993. Crustacea Amphipoda: lysianassoids from Philippine and Indonesian waters. In: Crosnier, A. (Ed.). Résultats des campagnes MUSORSTOM, Volume 10. Mémoires du Muséum National d'Histoire Naturelle, Serie A, Zoology, 156: 55-109.

Lowry, J.K. \& Stoddart, H.E. 1994. Crustacea Amphipoda: lysianassoids from the tropical western South Pacific Ocean. In: Crosnier, A. (Ed.). Résultats des campagnes MUSORSTOM, Volume 12. Mémoires du Muséum National d'Histoire Naturelle, Serie A, Zoology, 161: 127-223.

Lowry, J.K. \& Stoddart, H.E. 1997. Amphipoda Crustacea IV. Families Aristiidae, Cyphocarididae, Endevouridae, Lysianassidae, Scopelocheiridae, Uristidae. Memories of the Hourglass Cruises, 10: 1-148.

Pérez-Schultheiss, J. 2016. Synopsis of the superfamily Lysianassoidea (Amphipoda: Gammaridea) in Chile. Boletín del Museo Nacional de Historia Natural, Chile, 65: 193-246.

Rybakova, E., Galkin, S., Bergmann, M., Soltwedel, T. \& Gebruk, A. 2013. Density and distribution of megafauna at the Hakon Mosby mud volcano (the Barents Sea) based on image analysis. Biogeosciences, 10: 3359-3374.

Sellanes, J., Quiroga, E. \& Neira, C. 2008. Megafauna community structure and trophic relationships at the recently discovered Concepción Methane Seep Area, Chile, $\sim 36^{\circ}$ S. ICES Journal of Marine Science, 65: 1102-1111.

Sellanes, J., Neira, C., Quiroga, E. \& Teixido, N. 2010. Diversity patterns along and across the Chilean margin: a continental slope encompassing oxygen gradients and methane seep benthic habitats. Marine Ecology, 31: 11-124.

Vinogradov, G.M. 1990. Pelagic amphipods (Amphipoda, Crustacea) from the south-eastern Pacific. Transactions of the P.P. Shirshov Institute of Oceanology, 124: $27-104$.

Vinogradov, G.M. 2004. Near-bottom and pelagic gammaridean amphipods in the Western Indian Ocean. Annals of the South African Museum, 112: 39-88.

Winfield, I., Hendrickx, M.E. \& Ortiz, M. 2016. A new deep-water species of Trischizostoma (Crustacea: Amphipoda: Gammaridea: Trischizostomatidae) from western Mexico, NE Pacific Ocean. Journal of the Marine Biological Association of the United Kingdom, 97: 141-149. 